\title{
Effect of adding clay with or without a Saccharomyces cerevisiae fermentation product on the health and performance of lactating dairy cows challenged with dietary aflatoxin $B_{1}$
}

\author{
Y. Jiang, ${ }^{*}$ I. M. Ogunade, ${ }^{*} †$ D. H. Kim, ${ }^{*}$ X. Li, $\ddagger$ A. A. Pech-Cervantes, ${ }^{*}$ K. G. Arriola, ${ }^{*}$ A. S. Oliveira, $\S$ \\ J. P. Driver, ${ }^{*}$ L. F. Ferraretto, ${ }^{*}$ C. R. Staples, ${ }^{*}$ D. Vyas, ${ }^{*}$ and A. T. Adesogan* ${ }^{1}$ \\ *Department of Animal Sciences, University of Florida, Gainesville 32611 \\ †Division of Food and Animal Science, Kentucky State University, Frankfort 40601 \\ ‡Department of Animal Sciences, China Agricultural University, Beijing, China, 100193 \\ §Institute of Agriculture and Environmental Sciences, Federal University of Mato Grosso, Sinop, MT, Brazil, 78557-267
}

\begin{abstract}
The study was conducted to examine the effect of supplementing bentonite clay with or without a Saccharomyces cerevisiae fermentation product (SCFP; $19 \mathrm{~g}$ of NutriTek +16 g of MetaShield, both from Diamond V, Cedar Rapids, IA) on the performance and health of dairy cows challenged with aflatoxin $\mathrm{B}_{1}\left(\mathrm{AFB}_{1}\right)$. Twenty-four lactating Holstein cows $(64 \pm 11 \mathrm{~d}$ in milk) were stratified by parity and milk production and randomly assigned to 1 of 4 treatment sequences. The experiment had a balanced $4 \times 4$ Latin square design with 6 replicate squares, four 33 -d periods, and a 5 -d washout interval between periods. Cows were fed a total mixed ration containing $36.1 \%$ corn silage, $8.3 \%$ alfalfa hay, and $55.6 \%$ concentrate (dry matter basis). Treatments were (1) control (no additives), (2) toxin ( $\mathrm{T} ; 1,725 \mu \mathrm{g}$ of $\mathrm{AFB}_{1} /$ head per day), (3) $\mathrm{T}+$ clay (CL; $200 \mathrm{~g} /$ head per day; top-dressed), and (4) CL+SCFP (CL+SCFP; $35 \mathrm{~g} /$ head per day; top-dressed). Cows were adapted to diets from d 1 to 25 (predosing period) and then orally dosed with $\mathrm{AFB}_{1}$ from d 26 to 30 (dosing period), and $\mathrm{AFB}_{1}$ was withdrawn from d 31 to 33 (withdrawal period). Milk samples were collected twice daily from d 21 to 33 , and plasma was sampled on d 25 and 30 before the morning feeding. Transfer of ingested $\mathrm{AFB}_{1}$ into milk aflatoxin $\mathrm{M}_{1}\left(\mathrm{AFM}_{1}\right)$ was greater in $\mathrm{T}$ than in $\mathrm{CL}$ or CL+SCFP (1.65 vs. 1.01 and $0.94 \%$, respectively) from d 26 to 30 . The CL and CL+SCFP treatments reduced milk $\mathrm{AFM}_{1}$ concentration compared with $\mathrm{T}$ (0.45 and 0.40 vs. $0.75 \mu \mathrm{g} / \mathrm{kg}$, respectively), and, unlike $\mathrm{T}$, both CL and CL+SCFP lowered $\mathrm{AFM}_{1}$ concentrations below the US Food and Drug Administration action
\end{abstract}

Received August 11, 2017.

Accepted November 21, 2017.

${ }^{1}$ Corresponding author: adesogan@ufl.edu level $(0.5 \mu \mathrm{g} / \mathrm{kg})$. Milk yield tended to be greater during the dosing period in cows fed CL+SCFP compared with T (39.7 vs. $37.7 \mathrm{~kg} / \mathrm{d}$ ). Compared with that for T, plasma glutamic oxaloacetic transaminase concentration, indicative of aflatoxicosis and liver damage, was reduced by CL ( 85.9 vs. $95.2 \mathrm{U} / \mathrm{L}$ ) and numerically reduced by CL+SCFP (87.9 vs. 95.2 U/L). Dietary CL and CL+SCFP reduced transfer of dietary $\mathrm{AFB}_{1}$ to milk and milk $\mathrm{AFM}_{1}$ concentration. Only CL prevented the increase in glutamic oxaloacetic transaminase concentration, and only CL+SCFP prevented the decrease in milk yield caused by $\mathrm{AFB}_{1}$ ingestion.

Key words: aflatoxin, Saccharomyces cerevisiae fermentation product, clay, milk

\section{INTRODUCTION}

Mycotoxins are secondary metabolites produced by fungal organisms (Reddy et al., 2010). A multiannual survey on the worldwide occurrence of mycotoxins showed that almost all livestock feedstuffs, including concentrates, forages, and preserved feeds such as hay and silage, contained at least 1 mycotoxin (Rodrigues and Naehrer, 2012). Aflatoxins are a family of structurally related mycotoxins produced mainly by Aspergillus flavus and Aspergillus parasiticus in warm and humid seasons (Gourama and Bullerman, 1995; Sales and Yoshizawa, 2005). Aflatoxin $\mathrm{B}_{1}\left(\mathbf{A F B}_{1}\right)$ is the most potent carcinogen among all aflatoxins, and up to $6 \%$ of dietary $\mathrm{AFB}_{1}$ can be transferred into milk as hydroxy$\mathrm{AFB}_{1}$ and aflatoxin $\mathrm{M}_{1}\left(\mathbf{A F M}_{1}\right.$; Galvano et al., 1996; EFSA, 2004; Upadhaya et al., 2010). Milk $\mathrm{AFM}_{1}$ represents a safety risk in milk and milk products because of its carcinogenicity (IARC, 2002; Liu and Wu, 2010). The US Food and Drug Administration (FDA) regulatory limit on the maximum permissible amount of $\mathrm{AFM}_{1}$ in milk is $0.5 \mu \mathrm{g} / \mathrm{kg}$, and that of $\mathrm{AFB}_{1}$ in dairy feeds is $20 \mu \mathrm{g} / \mathrm{kg}$, whereas the maximum milk $\mathrm{AFM}_{1}$ 
concentration allowed by the European Commission is $0.05 \mu \mathrm{g} / \mathrm{kg}$ (EFSA, 2004). Regulatory authorities set limits on milk $\mathrm{AFM}_{1}$ concentration because of the appreciable amounts of milk humans, particularly infants, consume and because of the negative effects of $\mathrm{AFM}_{1}$ on human health (FDA, 2000). In addition to the public health concerns, chronic exposure to aflatoxins in diets of lactating cows can cause reduced performance, impaired liver function, suppressed immune status, and increased susceptibility to diseases (Fink-Gremmels, 2008; Hasheminya and Dehghannya, 2013).

A feasible and cost-effective strategy for reducing the toxic effects and transfer of aflatoxin into milk is to reduce its gastrointestinal bioavailability (CAST, 2003). When fed at approximately $1 \%$ of the diet DM, claybased sequestering agents are effective at impairing gastrointestinal absorption of the toxin such that milk $\mathrm{AFM}_{1}$ concentrations remain below the FDA threshold (Kutz et al., 2009; Queiroz et al., 2012; Maki et al., 2016). However, high doses of clay products may reduce vitamin and mineral utilization (Chestnut et al., 1992), and clay products have not consistently prevented decreases in milk yield caused by $\mathrm{AFB}_{1}$ ingestion (Kutz et al., 2009; Queiroz et al., 2012). In fact, Sulzberger et al. (2017) reported a linear decrease in the milk yield of dairy cows fed diets supplemented with increasing levels of clay $(0.5,1.0$, and $2 \%$ of diet DM) containing vermiculite, nontronite, and montmorillonite.

Saccharomyces cerevisiae fermentation products (SCFP) have potential to improve animal performance by modulating the gut microbiome, improving gut morphology, and reducing inflammatory responses (Jensen et al., 2015; Xiao et al., 2016). A meta-analytic summary of 36 studies revealed that SCFP supplementation increased DMI, milk yield, and milk fat and protein yield in lactating dairy cows (Poppy et al., 2012). Additionally, yeast products, particularly yeast cell wall glucans, were effective at binding relatively low doses of $\mathrm{AFB}_{1}(<60 \mu \mathrm{g} / \mathrm{kg}$; Diaz et al., 2004), though they have been ineffective when higher doses were fed (Kutz et al., 2009; Kissell et al., 2013). Therefore, combinations of SCFP with clay may reduce dietary aflatoxin transfer into the milk of cows and prevent milk yield reductions caused by the toxin. Recently, Ogunade et al. (2016) examined the efficacy of a sequestering agent based on a combination of SCFP, sodium bentonite clay, and chlorophyll-based additives at reducing aflatoxin-induced reductions in performance and inflammatory stress in dairy cows orally dosed with 73 $\mu \mathrm{g} / \mathrm{kg}$ of $\mathrm{AFB}_{1}$. The sequestering agents prevented the inflammatory stress response and anemia caused by the toxin but did not reduce milk $\mathrm{AFM}_{1}$ concentration or prevent the reduction in milk yield caused by the toxin.
More studies are needed to examine whether combinations of clay and SCFP at inclusion levels higher than those of Ogunade et al. (2016) can mitigate adverse $\mathrm{AFB}_{1}$ effects on milk $\mathrm{AFM}_{1}$ concentration and dairy cow performance. Therefore, this study examined the effect of dietary addition of clay $(200 \mathrm{~g} / \mathrm{d}$ per cow $)$ with or without a high level of SCFP (35 g/d per cow) on the performance, milk $\mathrm{AFM}_{1}$ concentration, and immune response of dairy cows challenged with $\mathrm{AFB}_{1}$. We hypothesized that feeding supplemental clay alone would reduce transfer of $\mathrm{AFB}_{1}$ to milk and that the combination of clay and SCFP would have a similar effect but also prevent the reduction in milk production caused by the toxin.

\section{MATERIALS AND METHODS}

\section{Cow, Treatments, and Design}

Cows used in this study were cared for in accordance with guidelines approved by the University of Florida Institutional Animal Care and Use Committee. Twentyfour lactating multiparous (parity 2 to 4) Holstein cows in early lactation $(64 \pm 11$ DIM) were stratified by parity and milk production and randomly assigned to 1 of 4 treatment sequences arranged in a balanced $4 \times 4$ Latin square design with 6 replicate squares, four 33-d periods, and a 5 -d washout interval between periods. All cows were housed in a freestall open-sided sandbedded barn fitted with Calan gates (American Calan Inc., Northwood, NH) for individual feeding and with misters and fans for cooling once ambient temperature reached $21.1^{\circ} \mathrm{C}$. Data on the prevailing temperature and humidity during the trial were collected from the Florida Automated Weather Network (http://fawn.ifas .ufl.edu/). Dietary treatments were (1) control (basal diet without additives), (2) toxin ( $\mathbf{T}$; oral dose of 1,725 $\mu \mathrm{g}$ of $\mathrm{AFB}_{1} /$ head per day), (3) toxin with clay (CL; 200 g/head per day; Astra-Ben-20, Prince Agri Products Inc., Quincy, IL), and (4) CL plus SCFP (CL+SCFP; $35 \mathrm{~g}$ of SCFP/head per day). Astra-Ben-20 is a sodium bentonite-based flow, anticaking, and pelleting agent that has shown efficacy at sequestering aflatoxins in previous studies (Diaz et al., 2004; Kissell et al., 2013). The SCFP is a proprietary product containing $19 \mathrm{~g}$ of NutriTek and $16 \mathrm{~g}$ of MetaShield (Diamond V, Cedar Rapids, IA). Dietary ingredients and chemical composition are shown in Table 1. The basal diet was formulated to meet or exceed nutrient requirements of lactating dairy cows producing at least $30 \mathrm{~kg}$ of milk (NRC, 2001) with CPM-Dairy version 3.0.10 software (www.cpmdairy.net). Diets were fed as a TMR twice daily (0700 and $1500 \mathrm{~h})$ using a Calan data ranger 
(American Calan Inc.). The experimental animals were adapted to housing and milking conditions and trained to access feed from Calan gates for $10 \mathrm{~d}$ before the start of the trial. The first $25 \mathrm{~d}$ of each period were used to ensure adaptation to a new diet and clearance of milk aflatoxin residues from the preceding period. Cows in treatments T, CL, and CL+SCFP were orally dosed with $1,725 \mu \mathrm{g}$ of $\mathrm{AFB}_{1} /$ head per day from d 26 to 30 before the morning feeding to give a dietary concentration of $75 \mu \mathrm{g} / \mathrm{kg}$ of DM based on estimated daily DMI of $23 \mathrm{~kg} / \mathrm{d}$. The amount of toxin dosed was chosen based on our previous studies (Queiroz et al., 2012; Ogunade et al., 2016). Aflatoxin $B_{1}$ was obtained from the University of Missouri Diagnostic Laboratory (Columbia, $\mathrm{MO}$ ), and it was mixed with $10 \mathrm{~g}$ of ground corn and 4 $\mathrm{mL}$ of molasses and then weighed into gelatin capsules before orally dosing each cow daily. Control animals were provided with similar quantities of ground corn and molasses without $\mathrm{AFB}_{1}$ in the gelatin capsule.

The sequestering agents were top-dressed on the respective TMR from d 1 to 33 of each period. Days 21 to 25 , the last $5 \mathrm{~d}$ of the adaption period, were classified as the predosing period (d 21-25). Days 26 to 30 constituted the aflatoxin-dosing period, and d 31 to 33 constituted the withdrawal period. Previous studies conducted in our laboratory have confirmed that $3 \mathrm{~d}$ is a suitable duration for clearance of aflatoxin from the milk (Queiroz et al., 2012; Ogunade et al., 2016). A 5-d washout period was imposed after each withdrawal period to minimize carryover of treatment effects between periods.

\section{Experimental Measurements and Analytical Procedures}

Feed Intake. The amount of feed offered was recorded daily for each cow. Orts were collected and weighed each morning before feeding and used to calculate intakes for the next day. Diets were fed ad libitum $(110 \%$ of the previous day's DMI). Representative samples $(\sim 200 \mathrm{~g})$ of the TMR offered and orts were collected daily and dried at $55^{\circ} \mathrm{C}$ for $48 \mathrm{~h}$ in a forced-air oven for the DMI calculation.

Feed Sampling. Feed ingredients were sampled (100 g) daily from d 21 to 33 of each period and stored in a refrigerator $\left(4^{\circ} \mathrm{C}\right)$ for further analysis. Samples were dried in a forced-air oven at $55^{\circ} \mathrm{C}$ for $48 \mathrm{~h}$ and ground to pass through the 1-mm screen of a Wiley mill. Ingredient samples were composited into the TMR and analyzed for DM, CP, NDF, ADF, starch, ash, and minerals at the Dairy One Forage Testing Laboratory (Ithaca, NY). Nitrogen was measured by rapid combustion with a Macro Elemental N analyzer (AOAC International, 2000; Vario MAX CN, model no. 25.00-
Table 1. Ingredient and chemical composition of the experimental diet

\begin{tabular}{|c|c|}
\hline Item & Amount \\
\hline \multicolumn{2}{|c|}{ Ingredient composition, $\%$ of DM } \\
\hline Corn silage & 36.1 \\
\hline Alfalfa hay & 8.3 \\
\hline Wet brewers grain & 8.3 \\
\hline Corn meal & 14.1 \\
\hline Dried citrus pulp & 8.5 \\
\hline Soy hulls & 5.6 \\
\hline Soybean meal ( $47 \% \mathrm{CP})$ & 13.9 \\
\hline Mineral and vitamin $\operatorname{mix}^{1}$ & 3.7 \\
\hline Energy booster ${ }^{2}$ & 1.5 \\
\hline \multicolumn{2}{|l|}{ Chemical composition } \\
\hline DM, \% & 89.4 \\
\hline $\mathrm{CP}, \%$ & 17.4 \\
\hline $\mathrm{ADF}, \%$ & 19.8 \\
\hline NDF, \% & 32.4 \\
\hline Starch, \% & 22.8 \\
\hline TDN, \% & 71.5 \\
\hline Calcium, \% & 0.76 \\
\hline Phosphorus, \% & 0.34 \\
\hline Magnesium, \% & 0.33 \\
\hline Potassium, $\%$ & 1.44 \\
\hline Sodium, $\%$ & 0.47 \\
\hline Iron, $\mathrm{mg} / \mathrm{kg}$ & 193 \\
\hline Zinc, $\mathrm{mg} / \mathrm{kg}$ & 56 \\
\hline Copper, $\mathrm{mg} / \mathrm{kg}$ & 12 \\
\hline Manganese, $\mathrm{mg} / \mathrm{kg}$ & 35 \\
\hline Molybdenum, $\mathrm{mg} / \mathrm{kg}$ & 0.8 \\
\hline Aflatoxin, $\mathrm{mg} / \mathrm{kg}$ & $\mathrm{ND}^{3}$ \\
\hline Ochratoxin, $\mathrm{mg} / \mathrm{kg}$ & ND \\
\hline Zearalenone, $\mathrm{mg} / \mathrm{kg}$ & ND \\
\hline Deoxynivalenol, $\mathrm{mg} / \mathrm{kg}$ & ND \\
\hline
\end{tabular}

${ }^{1}$ Vitamin mineral mixture (\% as is): ProvAAL (Perdue AgriBusiness, Sussex County, DE) Lys and Met, 30; sodium bicarbonate, 28.5; DCAD Plus (Arm \& Hammer Animal Nutrition, Princeton, NJ), 13.0; calcium carbonate, 9.0; dicalcium phosphate, 7.0; magnesium oxide, 7.0; salt ( $\mathrm{NaCl}$ ), 3.5; Zinpro Availa-4, 1.2 (Zinpro Corp., Eden Prairie, MN); Sel-Plex1000, 0.6 (Alltech, Nicholasville, KY); Rumensin 90, 0.22 (Elanco, Eli Lilly, Indianapolis, IN).

${ }^{2}$ Energy booster (Milk Specialties Global Animal Nutrition, Eden Prairie, MN).

${ }^{3}$ Concentrations were below lower detection limits $(5 \mu \mathrm{g} / \mathrm{kg}$ for aflatoxins; $0.5 \mathrm{mg} / \mathrm{kg}$ for ochratoxin, zearalenone, and deoxynivalenol).

5003; Elementar, Hanau, Germany), and N values were multiplied by 6.25 to calculate CP. Dietary NDF and ADF concentrations were determined using the nonsequential method developed by Van Soest et al. (1991) using an Ankom 200 Fiber Analyzer (Ankom Technologies, Macedon, NY). Determination of NDF involved the use of heat-stable $\alpha$-amylase. Starch concentration was determined using the method developed by Bach Knudsen (1997) with a YSI 2700 Select Biochemistry Analyzer (YSI Inc., Yellow Springs, OH). Subsamples of the composited TMR were used for analyzing $\mathrm{AFB}_{1}$, ochratoxin, zearalenone, and deoxynivalenol using HPLC at the University of Missouri Veterinary Diagnostic Laboratory based on a procedure described previously (Kutz et al., 2009). 
Milk Production, Composition, and AFM $M_{1}$ Secretion. Cows were milked twice daily at 1300 and $0100 \mathrm{~h}$. Milk yield was recorded daily by the Afikim milk system (AfiLab mini laboratory, Afimilk Ltd., Kibbutz Afikim, Israel). Milk samples were collected at each milking from d 21 to 33 in each experimental period and analyzed for concentrations of milk fat, protein, lactose, and SCC using a Bentley 2000 near-infrared reflectance spectrophotometer (Bentley Instruments Inc., Chaska, MN) at Southeast Milk dairy laboratory (Bellevue, FL). Values of $3.5 \%$ FCM were calculated using the equation $(0.4324 \times$ milk yield $)+$ $(16.218 \times$ milk fat yield) $($ NRC, 2001), and milk yield and milk components yield were calculated. Milk collected from experimental cows was discarded from the day toxin dosing was initiated until $\mathrm{AFM}_{1}$ levels in the milk were below the safety limit stipulated by the FDA $(0.5 \mu \mathrm{g} / \mathrm{kg})$. Milk $\mathrm{AFM}_{1}$ concentrations were measured on composited a.m. and p.m. milk samples from d 25 to 33 in each experimental period using the RIA test (CHARM II, Charm Sciences Inc., Malden, MA) described by Diaz et al. (2004) that was validated with HPLC measurements in a ring test (Salter et al., 2006). Aflatoxin $\mathrm{M}_{1}$ excretion was calculated as the product of milk $\mathrm{AFM}_{1}$ concentration and milk yield. Transfer of the toxin into milk was calculated by dividing daily milk $\mathrm{AFM}_{1}$ excretion by daily $\mathrm{AFB}_{1}$ ingestion (1,725 $\mu \mathrm{g})$. For the withdrawal period, the $\mathrm{AFM}_{1}$ transfer rate was calculated by dividing the daily $\mathrm{AFM}_{1}$ excretion by $\mathrm{AFB}_{1}$ ingestion on d $30(1,725 \mu \mathrm{g})$. Aflatoxin $\mathrm{M}_{1}$ clearance rates were calculated by dividing the difference between the milk $\mathrm{AFM}_{1}$ concentrations on d 31, 32, and 33 (withdrawal period) and $\mathrm{AFM}_{1}$ concentrations on $\mathrm{d}$ 30 of the dosing period by 24,48 , and $72 \mathrm{~h}$, respectively (Ogunade et al., 2016).

Blood Immune Response Indices. In each experimental period, blood samples were collected from cows in 3 of the 6 squares that were randomly selected at the beginning of the experiment. On d 25 and 30 of each experimental period, $15 \mathrm{~mL}$ of blood was sampled from the coccygeal vessels into evacuated tubes containing sodium heparin anticoagulant, centrifuged at 2,500 $\times$ $g$ for $20 \mathrm{~min}$ at $4^{\circ} \mathrm{C}$, and stored at $-20^{\circ} \mathrm{C}$ for further analysis. Plasma haptoglobin concentration was measured by determining haptoglobin and hemoglobin complexing based on differences in the peroxidase activity (Makimura and Suzuki, 1982). Plasma ceruloplasmin concentration was measured by determining ceruloplasmin oxidase activity using a colorimetric procedure (Demetriou et al., 1974). Plasma fibrinogen concentration was determined using a kit (Sigma procedure no. f8630; Sigma-Aldrich, St. Louis, MO) as described by Arthington et al. (2003). Acid-soluble proteins were measured using the Sigma Diagnostics bicinchoninic acid kit following plasma acid-soluble protein extraction (Nakajima et al., 1982). Liver function enzymes (alkaline phosphatase, glutamic pyruvic transaminase, glutamic oxaloacetic transaminase, $\gamma$-glutamyl transferase), bilirubin, and albumin concentrations in plasma were measured as described by Thomas (1998) using a fully automated Dimension Xpand Plus clinical chemistry analyzer (Siemens, Tarrytown, NY).

Whole blood samples were used to measure blood cell counts, neutrophil phagocytosis, and oxidative burst activities immediately after sample collection. Blood cell counts were measured using the automated ProCyte Dx hematology analyzer (Idexx Laboratories Inc., Westbrook, ME). The percentages of neutrophils exhibiting phagocytosis and oxidative burst activities after Escherichia coli challenge were measured as described by Martinez et al. (2012). Neutrophils were first loaded with dihydrorhodamine 123 (Sigma-Aldrich) and then cocultured with propidium iodide-labeled Escherichia coli at a bacteria:neutrophil ratio of 40:1. Samples were run within $2 \mathrm{~h}$ after preparation using a Becton Dickinson Accuri C6 digital analyzer flow cytometer (Becton Dickinson, Franklin Lakes, NJ). Data were analyzed with FlowJo version 7.6.5 (Tree Star Inc., Ashland, OR). Neutrophil adhesion molecules, L-selectin, and 32-integrin (CD62 and CD18, respectively) were analyzed as described by Silvestre et al. (2011). Median fluorescence intensity was used as a proxy to indicate activities of the adhesion molecules.

\section{Statistical Analysis}

Data were analyzed using the GLIMMIX procedure of SAS version 9.4 (SAS Institute Inc., Cary, NC). The model for analyzing outcomes (milk production and components, DMI, aflatoxin concentration, transfer, and excretion) that were measured repeatedly over time on the same experimental unit had the form

$$
\begin{gathered}
Y=\mu+T_{i}+P_{j}+D_{k}+C_{l}+S_{m}+C_{n} \\
+(T \times P)_{i j}+(T \times S)_{i m}+(P \times S)_{j m}+\varepsilon_{i j k l m n},
\end{gathered}
$$

where $\mu$ is the overall mean; $T_{i}$ is the effect of treatment; $\mathrm{P}_{\mathrm{j}}$ is the effect of experimental period; $\mathrm{D}_{k}$ is the effect of day; $\mathrm{CV}_{\mathrm{n}}$ is the effect of covariate; $(\mathrm{T} \times \mathrm{P})_{\mathrm{ij}}$ is interaction of treatment and experimental period; $\mathrm{C}_{l}$, $\mathrm{S}_{\mathrm{m}},(\mathrm{T} \times \mathrm{S})_{\mathrm{im}}$, and $(\mathrm{P} \times \mathrm{S})_{\mathrm{jm}}$ are the random effects of cow, square, interaction of treatment and square, and interaction of experimental period and square, respectively; and $\varepsilon_{\mathrm{ijklmn}}$ is the residual error . Cow within experimental period was used as the subject, and autore- 
gressive order 1 was used as the time-series covariance structure selected based on smallest Akaike information criterion values. Pre-experimental DMI, milk yield, and concentrations of milk components were used as covariates for respective variables measured during predosing, dosing, and withdrawal periods. Somatic cell counts were $\log$-transformed (base 2) for statistical analysis. Resulting least squares means and standard errors of the mean were transformed back to the original scale and reported as SCC.

The model for analyzing measures that were not collected serially on the same experimental unit (blood cell counts and immune response data) had the form

$$
\begin{aligned}
\mathrm{Y}=\mu & +\mathrm{T}_{\mathrm{i}}+\mathrm{P}_{\mathrm{j}}+\mathrm{C}_{\mathrm{l}}+\mathrm{S}_{\mathrm{m}}+\mathrm{CV}_{\mathrm{n}}+(\mathrm{T} \times \mathrm{P})_{\mathrm{ij}} \\
& +(\mathrm{T} \times \mathrm{S})_{\mathrm{im}}+(\mathrm{P} \times \mathrm{S})_{\mathrm{jm}}+\varepsilon_{\mathrm{ijklmn}},
\end{aligned}
$$

where $\mu$ is the overall mean; $\mathrm{T}_{\mathrm{i}}, \mathrm{P}_{\mathrm{j}}, \mathrm{CV}_{\mathrm{n}}$, and $(\mathrm{T} \times$ $\mathrm{P})_{\mathrm{ij}}$ are effects of treatment, experimental period, covariate, and interaction of treatment and experimental period, respectively; $\mathrm{C}_{1}, \mathrm{~S}_{\mathrm{m}},(\mathrm{T} \times \mathrm{S})_{\mathrm{im}},(\mathrm{P} \times \mathrm{S})_{\mathrm{jm}}$ are random effects of cow, square, interaction of treatment and square, and interaction of experimental period and square, respectively; and $\varepsilon_{\mathrm{ijklmn}}$ is the residual error. Data from blood samples collected on d 25 of each experimental period were used as covariates for analyzing data obtained during the toxin-dosing period. Denominator degrees of freedom were estimated by the Kenward-Roger option in the MODEL statement for all parameters. Tukey-Kramer pairwise multiple comparisons were used for post hoc mean comparisons. Significance was declared at $P \leq 0.05$, and tendencies to significance were declared at $0.05<P \leq 0.10$.

\section{RESULTS AND DISCUSSION}

\section{$A F M_{1}$ Concentration, Excretion, and Transfer}

Aflatoxin $\mathrm{M}_{1}$ was not detected in the milk of experimental cows during the last day of the predosing period (d 25) in any of the treatments (Figure 1). During the toxin-dosing period, cows on T, CL, and CL+SCFP treatments received $1,725 \mu \mathrm{g}$ of $\mathrm{AFB}_{1}$ daily. The average DMI for cows receiving $\mathrm{AFB}_{1}$ was $27.2 \mathrm{~kg} / \mathrm{d}$, resulting in an average daily $\mathrm{AFB}_{1}$ ingestion of $63.4 \mu \mathrm{g} / \mathrm{kg}$ of DMI. The $\mathrm{AFB}_{1}$ supplementation level in this study is within the range $(20-100 \mu \mathrm{g} / \mathrm{kg})$ supplemented in previous aflatoxin challenge studies (Diaz et al., 2004; Xiong et al., 2015; Pantaya et al., 2016) and lower than levels in challenge studies with naturally contaminated dairy diets $(120 \mu \mathrm{g} / \mathrm{kg}$, Guthrie, 1979; up to $94 \mu \mathrm{g} /$ $\mathrm{kg}$, Price et al., 1985), though natural contamination levels exceeding 1,000 $\mu \mathrm{g} / \mathrm{kg}$ are possible (Arnold and Gaskill, 2017). Although the daily $\mathrm{AFB}_{1}$ intake was lower than the targeted $75 \mu \mathrm{g} / \mathrm{kg}$ of DMI, the ingested $\mathrm{AFB}_{1}$ was sufficient to increase milk $\mathrm{AFM}_{1}$ concentration beyond the FDA action level of $0.50 \mu \mathrm{g} / \mathrm{kg}$ in cows fed diet $\mathrm{T}$ (Figure 1) during the toxin-dosing period (d 26-30). Aflatoxin $\mathrm{M}_{1}$ was not detected in the milk from cows fed the control diet; however, for T, CL, and $\mathrm{CL}+\mathrm{SCFP}$, average milk $\mathrm{AFM}_{1}$ concentration was 0.75 (the upper detection limit of the test), 0.44, and $0.40 \mu \mathrm{g} / \mathrm{kg}$ of $\mathrm{AFM}_{1}$, respectively (Table 2), during the toxin-dosing period (d 26-30). Adding $\mathrm{T}$ to the diet without sequestering agents resulted in greater $(P<0.01)$ milk $\mathrm{AFM}_{1}$ concentrations than $\mathrm{CL}$ and $\mathrm{CL}+\mathrm{SCFP}$ throughout the toxin-dosing period. In addition, $\mathrm{CL}$ or $\mathrm{CL}+\mathrm{SCFP}$ prevented milk $\mathrm{AFM}_{1}$ concentrations from increasing beyond the FDA action level $(0.50 \mu \mathrm{g} / \mathrm{kg})$ except during the first day (d 26) after dosing commenced (Figure 1) and reduced $\left(P<0.01\right.$; Table 2) excretion and transfer of $\mathrm{AFM}_{1}$ into milk. Clay minerals can adsorb substances such as aflatoxins on their external surfaces because each silica molecule is positively charged and surrounded by 4 negatively charged oxygen ions, forming a porous structure that can trap aflatoxins (Jouany, 2007; Velde and Meunier, 2008). Diaz et al. (2004) reported that 3 sodium bentonite products reduced $\mathrm{AFM}_{1}$ residues by 50 to $65 \%$ in the milk of dairy cows fed $100 \mu \mathrm{g} / \mathrm{kg}$ of dietary aflatoxins. Our previous study also showed that a high dose of montmorillonite clay (1\% of diet $\mathrm{DM}$ ) reduced milk $\mathrm{AFM}_{1}$ concentration below the FDA threshold but that a low dose $(0.2 \%$ of diet $\mathrm{DM})$ did not (Queiroz et al., 2012). Kissell et al. (2013) detected a $60.4 \%$ reduction in milk $\mathrm{AFM}_{1}$ concentration in dairy cows fed a diet contaminated with $91.0 \mu \mathrm{g} / \mathrm{kg}$ of $\mathrm{AFB}_{1}$ when the same bentonite clay product (Astra-Ben-20; $227 \mathrm{~g} /$ cow per day) used in this study was added to the diet. Furthermore, Maki et al. (2016) reported 55 and $68 \%$ reduction in milk $\mathrm{AFM}_{1}$ concentration with low $(0.5 \%)$ or high $(1 \%$ of diet DM) doses of a calcium montmorillonite clay, respectively, when dairy cows were fed diets contaminated with $121 \mu \mathrm{g} / \mathrm{kg}$ of $\mathrm{AFB}_{1}$. Recently, Sulzberger et al. (2017) also reported 19 to $42 \%$ reduction in milk $\mathrm{AFM}_{1}$ concentration by feeding a diet containing 0.5 to $2 \%$ (DM basis) of a clay product (containing a mixture of vermiculite, nontronite, and montmorillonite) to cows challenged with $100 \mu \mathrm{g} / \mathrm{kg}$ of $\mathrm{AFB}_{1}$. These studies conclusively indicate that clay products can reduce milk $\mathrm{AFM}_{1}$ concentrations in dairy cow diets, though the efficacy varies with the dose.

The efficacy of CL+SCFP at reducing milk $\mathrm{AFM}_{1}$ concentration, excretion, and transfer appears to be largely due to $\mathrm{CL}$, as the extent of reduction in milk 


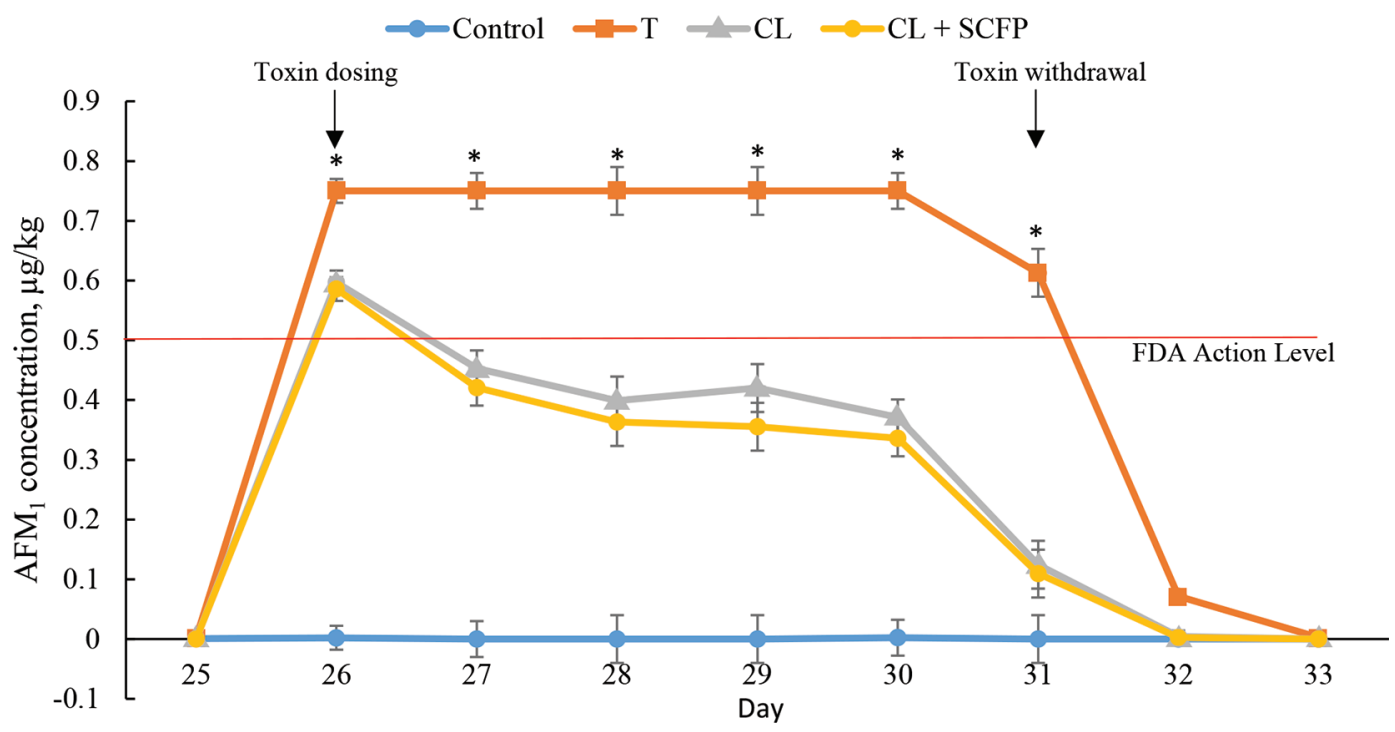

Figure 1. Effect of dosing aflatoxin $\mathrm{B}_{1}\left(\mathrm{AFB}_{1}\right)$ with or without sequestering agents based on Saccharomyces cerevisiae fermentation product (Diamond V, Cedar Rapids, IA) and clay on the concentration of aflatoxin $\mathrm{M}_{1}\left(\mathrm{AFM}_{1}\right)$ in the milk of dairy cows during the toxin-dosing (d 26-30) and withdrawal (d 31-33) periods. $\mathrm{T}=$ control diet $+\mathrm{AFB}_{1}(1,725 \mu \mathrm{g} / \mathrm{d}) ; \mathrm{CL}=\mathrm{T}+200 \mathrm{~g} / \mathrm{d}$ of bentonite clay; $\mathrm{CL}+\mathrm{SCFP}=\mathrm{CL}+35$ $\mathrm{g} / \mathrm{d}$ of Saccharomyces cerevisiae fermentation product. Asterisk indicates $P$-value $<0.01$. Error bars indicate SE on each day. FDA $=$ US Food and Drug Administration. Color version available online.

Table 2. Effects of dosing aflatoxin $\mathrm{B}_{1}\left(\mathrm{AFB}_{1}\right)$ with or without sequestering agents based on Saccharomyces cerevisiae fermentation product ${ }^{1}$ and clay on the transfer of the toxin to milk and the excretion, concentration, and clearance of aflatoxin $\mathrm{M}_{1}\left(\mathrm{AFM}_{1}\right)$ from the milk of dairy cows

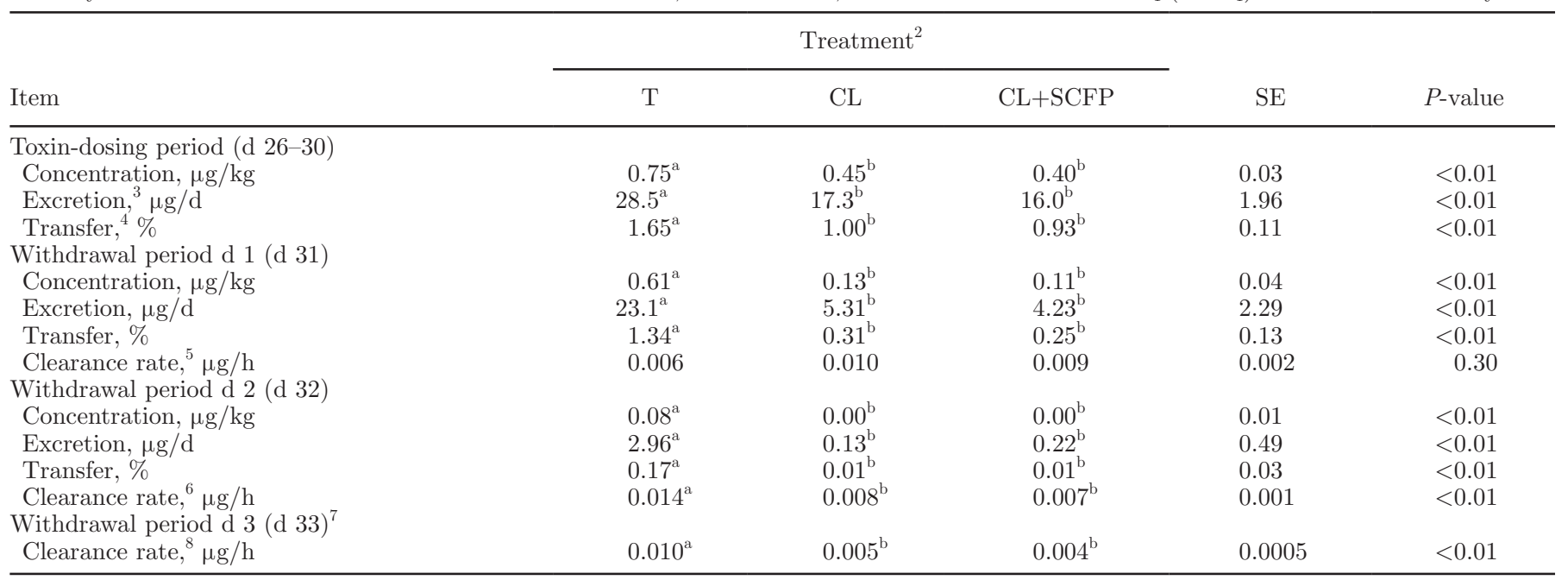

a,b Means within a row with no common superscripts differ $(P \leq 0.05)$.

${ }^{1}$ Saccharomyces cerevisiae fermentation product-based sequestering agent (Diamond V, Cedar Rapids, IA).

${ }^{2} \mathrm{~T}=$ control diet $+\mathrm{AFB}_{1}(1,725 \mu \mathrm{g} / \mathrm{d}) ; \mathrm{CL}=\mathrm{T}+200 \mathrm{~g} / \mathrm{d}$ of sodium bentonite clay; $\mathrm{CL}+\mathrm{SCFP}=\mathrm{CL}+35 \mathrm{~g} / \mathrm{d}$ of Saccharomyces cerevisiae fermentation product. No milk $\mathrm{AFM}_{1}$ was detected for the control cows.

${ }^{3}$ Excretion, $\mu \mathrm{g}=$ milk $\mathrm{AFM}_{1}$ concentration $(\mu \mathrm{g} / \mathrm{kg}) \times$ milk yield $(\mathrm{kg} / \mathrm{d})$.

${ }^{4}$ Transfer, $\%=100 \times\left[\right.$ excretion $(\mu \mathrm{g} / \mathrm{d}) / 1,725\left(\mu \mathrm{g}\right.$, daily $\mathrm{AFB}_{1}$ ingestion $\left.)\right]$.

${ }^{5}$ Clearance rate, $\mu \mathrm{g} / \mathrm{h}=\left[\mathrm{d}-30\right.$ milk $\mathrm{AFM}_{1}$ concentration $(\mu \mathrm{g} / \mathrm{kg})-\mathrm{d}-31$ milk $\mathrm{AFM}_{1}$ concentration $\left.(\mu \mathrm{g} / \mathrm{kg})\right] / 24(\mathrm{~h})$.

${ }^{6}$ Clearance rate, $\mu \mathrm{g} / \mathrm{h}=\left[\mathrm{d}-30\right.$ milk $\mathrm{AFM}_{1}$ concentration $(\mu \mathrm{g} / \mathrm{kg})-\mathrm{d}-32$ milk $\mathrm{AFM}_{1}$ concentration $\left.(\mu \mathrm{g} / \mathrm{kg})\right] / 48(\mathrm{~h})$.

${ }^{7} \mathrm{On}$ d $33, \mathrm{AFM}_{1}$ was not detected in all treatments.

${ }^{8}$ Clearance rate, $\mu \mathrm{g} / \mathrm{h}=\left[\mathrm{d}-30\right.$ milk $\mathrm{AFM}_{1}$ concentration $(\mu \mathrm{g} / \mathrm{kg})-\mathrm{d}-33$ milk $\mathrm{AFM}_{1}$ concentration $\left.(\mu \mathrm{g} / \mathrm{kg})\right] / 72(\mathrm{~h})$. 
$\mathrm{AFM}_{1}$ concentration was similar for both treatments (40 vs. $47 \%$ for CL and CL+SCFP, respectively). The efficacy of yeast products at reducing milk $\mathrm{AFM}_{1}$ concentration, excretion, and transfer, when supplemented without or with clay, is largely dependent on the level of dietary contamination with aflatoxins or the dose of clay or sequestering agent. Recent studies revealed no effects on milk $\mathrm{AFM}_{1}$ concentration when yeast-based products were added with low doses $(0.25 \%$ or $20 \mathrm{~g} /$ head per day) of clay to $\mathrm{AFB}_{1}$-contaminated diets. Xiong et al. (2015) reported no reduction in milk $\mathrm{AFM}_{1}$ concentration and transfer when sequestering agents based on sodium montmorillonite, live yeast, yeast culture, mannan oligosaccharide, and vitamin $\mathrm{E}$ were fed at $0.25 \%$ of the diet DM to cows challenged with $40 \mu \mathrm{g} / \mathrm{kg}$ of $\mathrm{AFB}_{1}$. Similarly, our recent study detected no reduction in milk $\mathrm{AFM}_{1}$ concentration, excretion, and transfer in dairy cows challenged with $73 \mu \mathrm{g} / \mathrm{kg}$ of $\mathrm{AFB}_{1}$ per day when mixtures of sodium bentonite clay, SCFP, and chlorophyll-based products were fed at 20 $\mathrm{g} /$ head per day (Ogunade et al., 2016). The results of the present study confirm the efficacy of CL in reducing milk $\mathrm{AFM}_{1}$ concentration below FDA action level, but no synergistic improvement was evident when $35 \mathrm{~g}$ of SCFP/head per day was added with CL.

During the withdrawal period (d 31-33), milk $\mathrm{AFM}_{1}$ concentrations of cows fed CL and CL+SCFP decreased rapidly within $24 \mathrm{~h}$, whereas those of cows fed diet $\mathrm{T}$ were still above the FDA action level after $24 \mathrm{~h}$ (Table 2; Figure 1). Adding CL or CL+SCFP also reduced ( $P$ $<0.0001$ ) excretion and transfer of $\mathrm{AFM}_{1}$ into milk on d 31. On d 2 of the withdrawal period (d 32), $\mathrm{AFM}_{1}$ was not detected in the milk of cows fed CL or CL+SCFP. However, trace concentrations of $\mathrm{AFM}_{1}(0.08 \mu \mathrm{g} / \mathrm{kg})$ were still detected $(P<0.01)$ in milk of cows fed diet $\mathrm{T}$. These results are consistent with previous findings that $\mathrm{AFM}_{1}$ levels in milk decrease drastically within 2 to $3 \mathrm{~d}$ of withdrawing $\mathrm{AFB}_{1}$ from the diet (Kutz et al., 2009; Queiroz et al., 2012; Xiong et al., 2015). The clearance rates of milk $\mathrm{AFM}_{1}$ were similar for T, CL, and $\mathrm{CL}+\mathrm{SCFP}$ treatments during $\mathrm{d} 1$ of the withdrawal period (d 31). However, on $\mathrm{d} 2$ and 3 of the toxin withdrawal period, greater average clearance rates $(P$ $<0.01$ ) were detected for cows fed diet $\mathrm{T}$ instead of CL or CL+SCFP. Aflatoxin $\mathrm{M}_{1}$ was not detected in milk samples of any cows on d 3 of the withdrawal period, indicating total clearance of the toxin within $3 \mathrm{~d}$ of its withdrawal from the diet. Similar results were observed in other studies after $72 \mathrm{~h}$ of $\mathrm{AFB}_{1}$ withdrawal from the diet of dairy cows (Queiroz et al., 2012; Ogunade et al., 2016), though trace levels of $\mathrm{AFM}_{1}$ were detected after a similar withdrawal period by Firmin et al. (2011).

\section{Animal Performance}

During the predosing period, the DMI and milk yield did not differ across treatments $(P>0.10)$ and averaged $27.4 \pm 0.47 \mathrm{~kg} / \mathrm{d}$ and $38.4 \pm 0.80 \mathrm{~kg} / \mathrm{d}$, respectively (Table 3). Similarly, no treatment effects were evident on the yield and concentrations of milk components $(P$ $>0.10)$ during the predosing period (d 21-25). These results indicate that feeding CL or CL+SCFP did not affect the performance of cows when they consumed diets that lacked $\mathrm{AFB}_{1}$; they may need to be fed for a longer period to elicit a response. Nevertheless, the results agree with previous studies in which DMI and milk yield were unaffected by addition of clay (Maki et al., 2016; Sulzberger et al., 2017) or a lower level of yeast-based sequestering agents to dairy cow diets (Ogunade et al., 2016).

During the toxin-dosing period, DMI averaged $27.4 \pm$ $0.52 \mathrm{~kg} / \mathrm{d}$ and was numerically $(P=0.14$; Table 3$) 1.2$ $\mathrm{kg} / \mathrm{d}$ lower for cows fed T compared with the control but statistically not different. The DMI results are consistent with previous studies (Kissell et al., 2013; Maki et al., 2016; Ogunade et al., 2016) showing no difference in intake levels by feeding $\mathrm{T}$ or sequestering agents. Milk yield tended to differ across dietary treatments $(P$ $=0.08)$. Cows fed CL+SCFP during the toxin-dosing period tended $(P=0.06)$ to produce more milk $(39.7$ $\mathrm{kg} / \mathrm{d})$ than cows fed $\mathrm{T}(37.7 \mathrm{~kg} / \mathrm{d})$, whereas cows fed CL had an intermediate response $(38.6 \mathrm{~kg} / \mathrm{d})$. As in this study, Diaz et al. (2004) and Maki et al. (2016) also reported that milk yield was not affected by supplementing bentonite (Astra-Ben-20) or montmorillonite clays, respectively, to cows consuming an $\mathrm{AFB}_{1}$-contaminated diet. The improvement in milk production by cows fed $\mathrm{CL}+\mathrm{SCFP}$ instead of $\mathrm{T}$ in the present study may be because the SCFP can improve ruminal fermentation and diet DM digestibility and prevent negative effects of $\mathrm{AFB}_{1}$ on these measures. For instance, $\mathrm{AFB}_{1}$ addition decreased ruminal microbial fermentation in vitro by reducing cellulose degradation, VFA and ammonia production, and DM digestibility (Jiang et al., 2012; Mojtahedi et al., 2013). Supplementation with SCFP in the present study may have reduced the negative effects of $\mathrm{AFB}_{1}$ on ruminal fermentation by providing a mixture of micronutrients that stimulate growth of rumen bacteria, thereby facilitating improved rumen fermentation and increased performance of dairy cows (Doležal et al., 2011; Patra, 2012). Several previous studies have shown that SCFP supplementation has improved ruminal fermentation or animal performance during stressful conditions that can compromise ruminal function, such as heat stress in lactating dairy cows 
Table 3. Effect of dosing aflatoxin $\mathrm{B}_{1}\left(\mathrm{AFB}_{1}\right)$ with or without sequestering agents based on Saccharomyces cerevisiae fermentation product ${ }^{1}$ and clay on the performance of dairy cows during predosing, toxin-dosing, and withdrawal periods

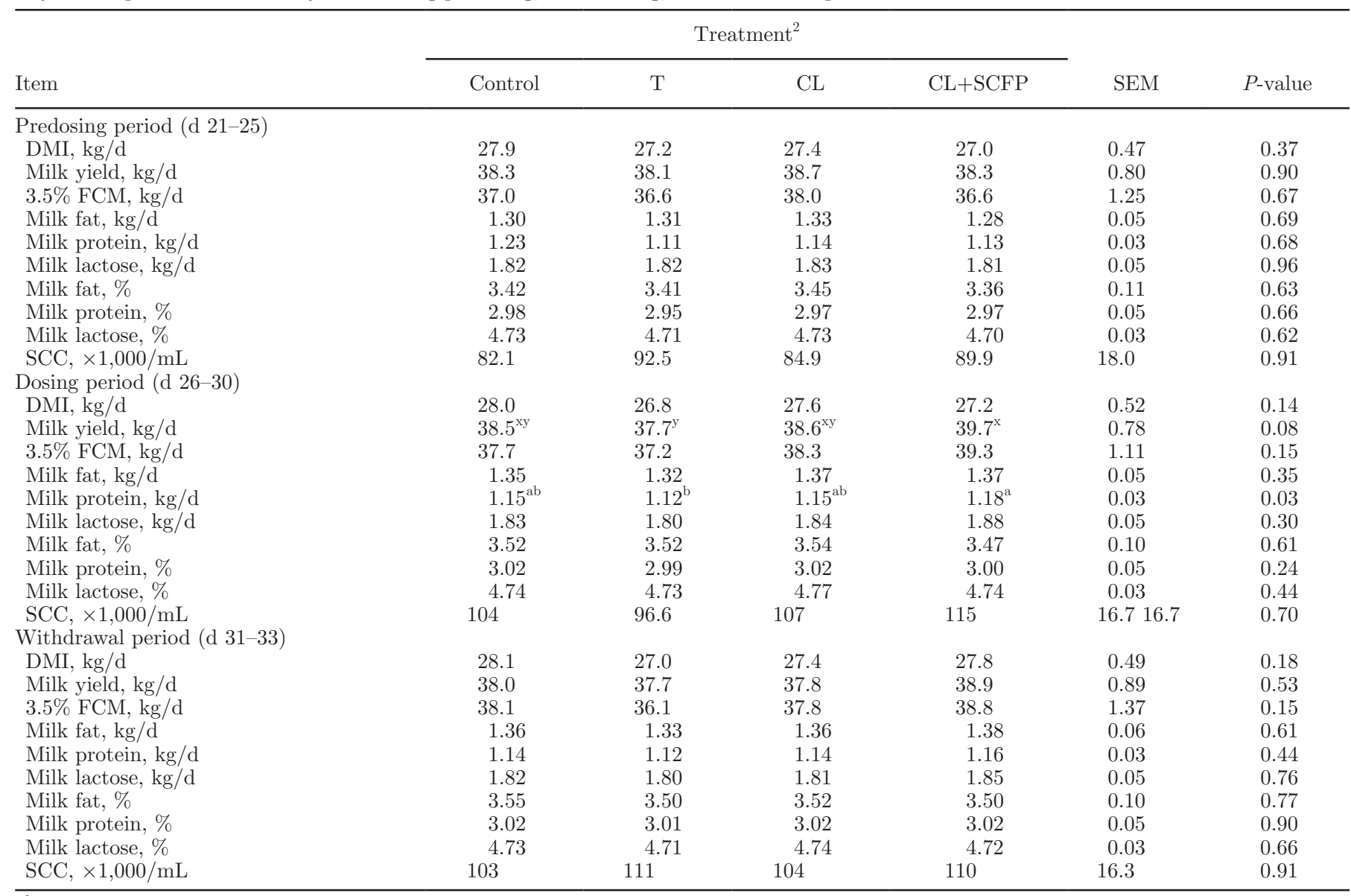

${ }^{\mathrm{a}, \mathrm{b}}$ Means within a row with no common superscripts differ $(P \leq 0.05)$.

${ }^{\mathrm{x}, \mathrm{y}}$ Means within a row with no common superscripts tend to differ $(0.05<P \leq 0.10)$.

${ }^{1}$ Saccharomyces cerevisiae fermentation product-based sequestering agent (Diamond V, Cedar Rapids, IA).

${ }^{2} \mathrm{~T}=$ control diet $+\mathrm{AFB}_{1}(1,725 \mu \mathrm{g} / \mathrm{d}) ; \mathrm{CL}=\mathrm{T}+200 \mathrm{~g} / \mathrm{d}$ of bentonite clay; CL+SCFP $=\mathrm{CL}+35 \mathrm{~g} / \mathrm{d}$ of Saccharomyces cerevisiae fermentation product.

(Schingoethe et al., 2004; Zhu et al., 2016; Acharya et al., 2017) or metabolic stress in transition dairy cows (Dann et al., 2000; Zaworski et al., 2014).

Milk protein yield was greater $(P=0.03)$ in cows receiving CL+SCFP compared with cows receiving only $\mathrm{T}(1.18$ vs. $1.12 \mathrm{~kg} / \mathrm{d})$. The milk protein yield response was probably driven by the increase in milk yield by CL+SCFP compared with $\mathrm{T}$, as no difference $(P>$ $0.10)$ in milk protein concentration was evident among these treatments. Although adding SCFP to CL did not increase milk production relative to the control diet, it did increase milk yield and milk protein concentration by 2 and $0.06 \mathrm{~kg} / \mathrm{d}$, respectively, relative to the toxin treatment during the toxin-dosing period. Thus, adding SCFP to CL was as effective at reducing milk aflatoxin concentration as CL alone, but it was more effective than CL alone at increasing the milk yield of cows fed the toxin. Thus, unlike CL alone, adding CL+SCFP to the diet may increase the milk yield of cows fed an $\mathrm{AFB}_{1}$-contaminated diet.

No other difference was observed in concentration or yields of milk components across dietary treatments. Lack of treatment effects on milk fat and protein concentration are consistent with previous findings. Kutz et al. (2009) reported that adding $112 \mu \mathrm{g}$ of $\mathrm{AFB}_{1} / \mathrm{kg}$ of diet DM did not affect the milk component concentrations of lactating dairy cows. Similarly, Maki et al. (2016) showed no effect of adding $100 \mu \mathrm{g}$ of a mixture of aflatoxin $\mathrm{B}_{1}, \mathrm{~B}_{2}, \mathrm{G}_{1}$, and $\mathrm{G}_{2}$, containing $79 \%$ of $\mathrm{AFB}_{1}$, per kilogram of DMI, with or without 0.5 to $1 \%$ of calcium montmorillonite clay, on milk fat, protein, and lactose concentrations. During the withdrawal period, 
Table 4. Effect of dosing aflatoxin $\mathrm{B}_{1}\left(\mathrm{AFB}_{1}\right)$ with or without sequestering agents based on Saccharomyces cerevisiae fermentation product ${ }^{1}$ and clay on the blood cell counts of dairy cows

\begin{tabular}{|c|c|c|c|c|c|c|}
\hline \multirow[b]{2}{*}{ Item } & \multicolumn{4}{|c|}{ Treatment $^{2}$} & \multirow[b]{2}{*}{$\mathrm{SE}$} & \multirow[b]{2}{*}{$P$-value } \\
\hline & Control & $\mathrm{T}$ & CL & $\mathrm{CL}+\mathrm{SCFP}$ & & \\
\hline White blood cells, $10^{3} / \mu \mathrm{L}$ & 19.0 & 18.0 & 18.3 & 17.6 & 0.50 & 0.20 \\
\hline Red blood cells, $10^{6} / \mu \mathrm{L}$ & 6.01 & 6.04 & 6.05 & 5.87 & 0.12 & 0.57 \\
\hline Neutrophils, $10^{3} / \mu \mathrm{L}$ & 3.79 & 3.52 & 3.79 & 3.56 & 0.53 & 0.37 \\
\hline Monocytes, $10^{3} / \mu \mathrm{L}$ & 1.50 & 1.28 & 1.46 & 1.47 & 0.34 & 0.89 \\
\hline Eosinophils, $10^{3} / \mu \mathrm{L}$ & 0.54 & 0.47 & 0.54 & 0.57 & 0.08 & 0.77 \\
\hline Lymphocytes, $10^{3} / \mu \mathrm{L}$ & 13.0 & 12.5 & 12.6 & 12.9 & 0.43 & 0.67 \\
\hline Basophils, $10^{3} / \mu \mathrm{L}$ & 0.005 & 0.002 & 0.003 & 0.004 & 0.003 & 0.74 \\
\hline Hemoglobin, $\mathrm{g} / \mathrm{dL}$ & 2.56 & 2.76 & 2.53 & 2.71 & 0.31 & 0.25 \\
\hline Hematocrit, $\%$ & 28.4 & 28.3 & 28.4 & 27.4 & 0.61 & 0.56 \\
\hline
\end{tabular}

DMI and milk yield and components did not differ $(P$ $>0.10)$ across dietary treatments, which is in agreement with Ogunade et al. (2016).

\section{Blood Cell Counts and Immune Response Indices}

Aflatoxins have negative effects on immune system function in cattle (Hussein and Brasel, 2001). Paul et al. (1977) demonstrated that $\mathrm{AFB}_{1}$ suppressed peripheral blood lymphocyte response to phytomitogens. Similarly, Bodine et al. (1984) reported strong inhibition of bovine lymphocyte blastogenesis by $\mathrm{AFB}_{1}$ and inhibition of $\mathrm{T}$ lymphocyte function by $\mathrm{AFB}_{1}$ metabolites. However, in this study, dietary addition of $\mathrm{AFB}_{1}$, with or without sequestering agents, had no effect $(P$ $>0.10$ ) on blood cell counts of dairy cows (Table 4 ). The results contradict those from our previous study where $\mathrm{AFB}_{1}$ reduced hemoglobin concentration and red blood cell counts in dairy cows (Ogunade et al., 2016), which may be due to the greater concentration of $\mathrm{AFB}_{1}$ $(73 \mu \mathrm{g} / \mathrm{kg})$ in that study. Data from both studies were within the normal range for healthy lactating Holstein dairy cows (8.4-12.2 g/dL for hemoglobin and 5.1-7.6 $\times 10^{6} / \mu \mathrm{L}$ for red blood cell counts; George et al., 2010). As in this study, no effects on blood cell counts of sheep were reported when diets contaminated with 32,64 , or $128 \mu \mathrm{g} / \mathrm{d}$ of $\mathrm{AFB}_{1}$ were fed (Battacone et al., 2003, 2005).

Acute phase proteins are blood proteins and health indicators that are primarily produced by hepatocytes in response to infection and inflammatory stress (Heegaard et al., 2000; Jain et al., 2011; Tothova et al., 2014). In this study, plasma haptoglobin, ceruloplasmin, acid-soluble protein, and fibrinogen concentrations were unaffected $(P>0.10)$ by treatment (Table 5$)$. In our earlier study (Queiroz et al., 2012), concentrations of plasma ceruloplasmin and fibrinogen were unaffected but plasma haptoglobin concentration was increased when cows were fed $75 \mu \mathrm{g} / \mathrm{kg}$ of $\mathrm{AFB}_{1}$ per day. However, Ogunade et al. (2016) reported no changes in plasma haptoglobin and ceruloplasmin concentrations but noted that acid-soluble protein concentration increased in cows fed $73 \mu \mathrm{g} / \mathrm{kg}$ of $\mathrm{AFB}_{1}$. The lack of treatment effects on acute phase proteins in this study may be attributed to greater DMI, which diluted the $\mathrm{AFB}_{1}$ intake $(63.4 \mu \mathrm{g} / \mathrm{kg}$ of $\mathrm{DMI})$ relative to those in our previous studies $(75 \mu \mathrm{g} / \mathrm{kg}$, Queiroz et al., 2012; 73 $\mu \mathrm{g} / \mathrm{kg}$ of DMI, Ogunade et al., 2016). Based on these results, we speculate that the dietary concentration of the ingested toxin is more important than the total amounts offered. Nevertheless, variable immune function responses in cows that ingested similar amounts of toxin have been reported and attributed to factors such as heat stress (Elvinger et al., 1992; do Amaral et al., 2010), clinical or subclinical disease (Petersen et al., 2002), and lactation stage (Mehrzad et al., 2001). However, because only a few studies have reported effects of $\mathrm{AFB}_{1}$ and aflatoxin-sequestering agents on acute phase proteins in dairy cows, more research in this area is needed.

No treatment effects were observed on the percentage of neutrophil cells exhibiting phagocytosis and oxidative burst activities or expressions of CD62L (L-selectin) and CD18 $\left(\beta_{2}\right.$-integrin; $P>0.10$; Table 5$)$. Percentages of neutrophils exhibiting phagocytosis and oxidative burst are indicative of neutrophil function (Kampen et al., 2004). Phagocytosis is the process of ingesting bacteria by phagocytes, whereas oxidative burst is the process of rapid release of reactive oxygen species, which is necessary for killing bacteria (Burvenich et al., 2003). The adhesion molecule L-selectin, is a protein that exists on the surface of neutrophils that can recognize endothe- 
Table 5. Effect of dosing aflatoxin $\mathrm{B}_{1}\left(\mathrm{AFB}_{1}\right)$ with or without sequestering agents based on yeast product ${ }^{1}$ and clay on the immune response indices of dairy cows

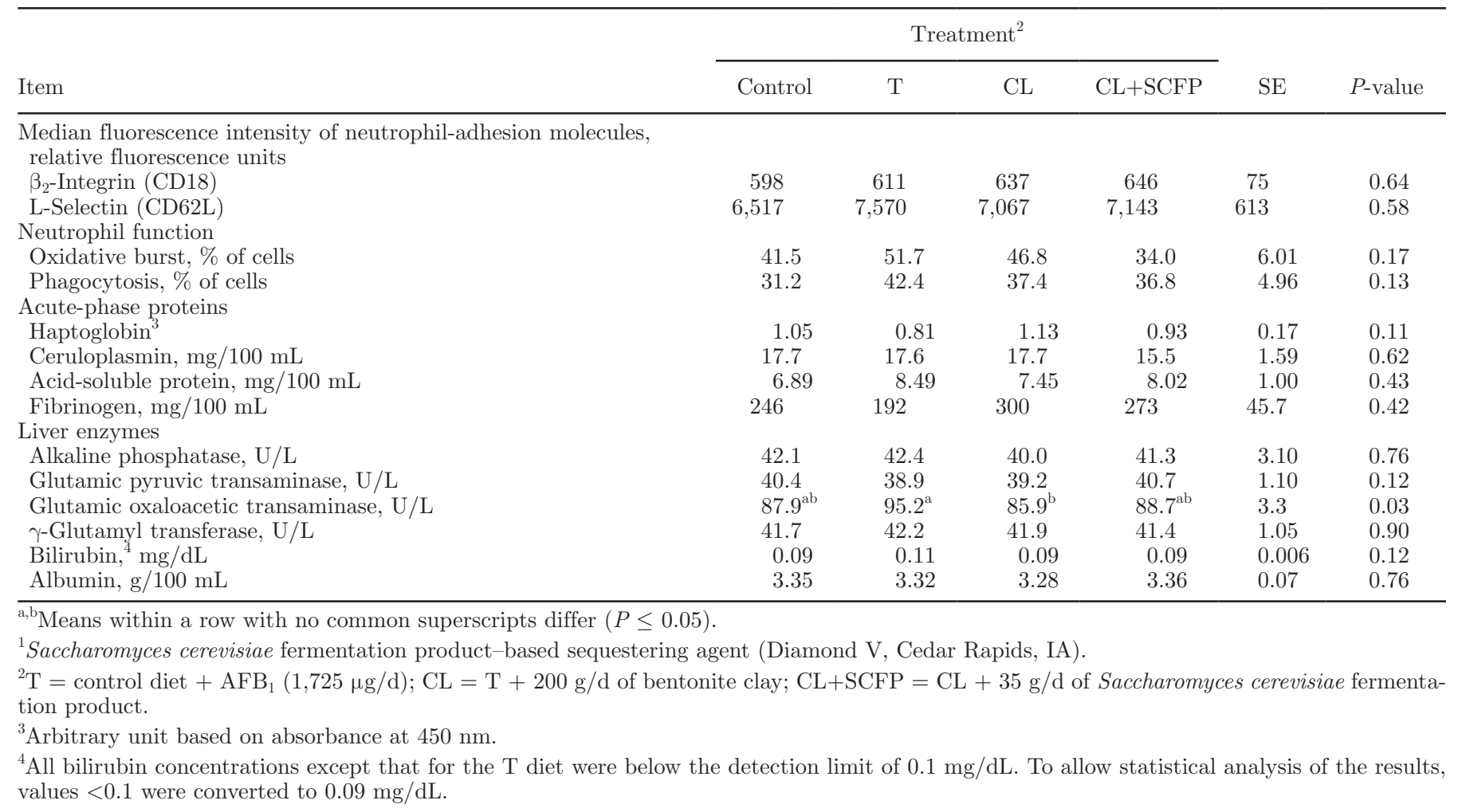

lial inflammatory signals (Amulic et al., 2012), whereas $\beta 2$-integrin is essential for both neutrophil recruitment and cytotoxic functions (Gakidis et al., 2004). Lack of treatment effects on neutrophil function indicators suggests that dosing $\mathrm{AFB}_{1}$ with or without the sequestering agents did not alter the immune status of the dairy cows; however, it is noteworthy that diet T numerically increased phagocytosis $(P=0.13)$ but that diets CL and CL+SCFP did not. This suggests a trend for diet $\mathrm{T}$ to heighten the immune status of the cows, whereas CL and CL+SCFP attenuated the response. A higher $\mathrm{AFB}_{1}$ dose or prolonged challenge with the toxin may have been needed to elicit the phagocytosis and oxidative burst activities. More studies are needed to confirm the effects of aflatoxins and aflatoxin-sequestering agents on neutrophil function.

Elevated levels of plasma function enzymes such as glutamic oxaloacetic transaminase and ornithine carbamyl transferase in response to aflatoxicosis are indicative of hepatocyte damage (Bang et al., 1959; Pier, 1992). Ornithine carbamyl transferase was not measured in this study, but plasma glutamic oxaloacetic transaminase was numerically higher in cows fed $\mathrm{T}$ than the control ( $P=0.11$; Table 5$)$, suggesting potential liver damage by feeding T. Feeding CL reduced (Table 5) the concentration of plasma glutamic oxaloacetic transaminase compared with $\mathrm{T}$, suggesting that CL may reduce aflatoxicosis and liver damage. This was possibly because CL reduced the absorption of $\mathrm{AFB}_{1}$ and thus reduced the need for the liver to detoxify it. The CL and $\mathrm{CL}+\mathrm{SCFP}$ diets both reduced the concentration and excretion of $\mathrm{AFM}_{1}$ in milk during the toxin-dosing period. However, although CL reduced the plasma concentration of glutamic oxaloacetic transaminase relative to T, CL+SCFP did not. The reason for the different responses is unclear and warrants additional research.

No treatment effects were observed on plasma concentrations of alkaline phosphatase, glutamic pyruvic transaminase, bilirubin, albumin, and $\gamma$-glutamyl transferase $(P>0.10$; Table 5). Xiong et al. (2015) reported that feeding a sequestering agent decreased malondialdehyde level and increased superoxide dismutase level in cows challenged with 20 or $40 \mu \mathrm{g}$ of $\mathrm{AFB}_{1} / \mathrm{kg}$ of diet DM per day for $7 \mathrm{~d}$, indicating reduced oxidative stress. However, other plasma parameters such as glutamic oxaloacetic transaminase and ornithine carbamyl transferase, indicative of depressed liver function, were not affected. Battacone et al. (2005) reported that levels of glutamic oxaloacetic transaminase, glutamic pyruvic transaminase, $\gamma$-glutamyl transpeptidase, alka- 
line phosphatase, and lactate dehydrogenase were not increased by feeding $\mathrm{AFB}_{1}$ to dairy sheep at 32,64 , and $128 \mu \mathrm{g} / \mathrm{d}$ for $7 \mathrm{~d}$. However, greater levels of plasma glutamic pyruvic transaminase and alkaline phosphatase, indicating liver damage, were reported in dairy sheep fed 32, 64, and $128 \mu \mathrm{g}$ of $\mathrm{AFB}_{1} / \mathrm{d}$ for $14 \mathrm{~d}$ (Battacone et al., 2003). The inconsistency among responses in these studies may be due to differences in the duration of the toxin-dosing periods $(5,7$, or $14 \mathrm{~d})$, aflatoxin concentrations $(20,40$, or $63 \mu \mathrm{g} / \mathrm{kg}$ and 32,64 , or $128 \mu \mathrm{g} / \mathrm{d}$ ), type of animals (sheep vs. cows), and composition of the sequestering agents.

\section{CONCLUSIONS}

Dietary addition of $\mathrm{AFB}_{1}$ increased milk $\mathrm{AFM}_{1}$ concentration beyond the FDA action level in lactating Holstein dairy cows. Sodium bentonite clay alone or combined with SCFP reduced transfer of dietary $\mathrm{AFB}_{1}$ into milk $\mathrm{AFM}_{1}$ and excretion of $\mathrm{AFM}_{1}$ in the milk such that mean milk $\mathrm{AFM}_{1}$ concentrations did not exceed the FDA action level. After withdrawing $\mathrm{AFB}_{1}$ from the diet, milk $\mathrm{AFM}_{1}$ concentrations decreased more quickly in cows fed CL or CL+SCFP and they were eliminated $24 \mathrm{~h}$ earlier than in those fed T. During the toxin-dosing period, milk yield tended to be greater for cows fed CL+SCFP than those fed T. Therefore, the $\mathrm{CL}+\mathrm{SCFP}$ supplement was better at maintaining milk production during the $\mathrm{AFB}_{1}$ challenge than CL alone. Furthermore, the concentration of plasma glutamic oxaloacetic transaminase was reduced when CL was fed instead of $\mathrm{T}$.

\section{ACKNOWLEDGMENTS}

We gratefully acknowledge Diamond V Inc. (Cedar Rapids, IA) for funding this study. We are also grateful to the staff of the University of Florida (Gainesville) dairy unit for their assistance with the study.

\section{REFERENCES}

Acharya, S., J. P. Pretz, I. Yoon, M. F. Scott, and D. P. Casper. 2017. Effect of Saccharomyces cerevisiae fermentation products on the lactational performance of mid-lactation dairy cows. Transl. Anim. Sci. 1:221-228.

Amulic, B., C. Cazalet, G. L. Hayes, K. D. Metzler, and A. Zychlinsky. 2012. Neutrophil function: From mechanisms to disease. Annu. Rev. Immunol. 30:459-489.

AOAC International. 2000. Official Methods of Analysis. 17th ed. AOAC International, Arlington, VA.

Arnold, M., and C. Gaskill. 2017. Mycotoxins and their effects on dairy cattle. Accessed Nov. 20, 2017. https://afs.ca.uky.edu/dairy/ mycotoxins-and-their-effects-dairy-cattle.

Arthington, J. D., S. D. Eicher, W. E. Kunkle, and F. G. Martin. 2003. Effect of transportation and commingling on the acute-phase protein response, growth, and feed intake of newly weaned calves. J. Anim. Sci. 81:1120-1125.
Bach Knudsen, K. E. 1997. Carbohydrate and lignin contents of plant materials used in animal feeding. Anim. Feed Sci. Technol. 67:319 338.

Bang, N. U., K. Iversen, T. Jagt, and G. Tobiassen. 1959. Serum glutamic-oxaloacetic transaminase activity as an index of centrilobular liver cell necrosis in cardiac and circulatory failure. Acta Med. Scand. 164:385-393.

Battacone, G., A. Nudda, A. Cannas, A. C. Borlino, G. Bomboi, and G. Pulina. 2003. Excretion of aflatoxin M1 in milk of dairy ewes treated with different doses of aflatoxin B1. J. Dairy Sci. 86:26672675 .

Battacone, G., A. Nudda, M. Palomba, M. Pascale, P. Nicolussi, and G. Pulina. 2005. Transfer of aflatoxin B1 from feed to milk and from milk to curd and whey in dairy sheep fed artificially contaminated concentrates. J. Dairy Sci. 88:3063-3069.

Bodine, A. B., S. F. Fisher, and S. Gangjee. 1984. Effect of aflatoxin B1 and major metabolites on phytohemeagglutinin-stimulated lymphoblastogenesis of bovine lymphocytes. J. Dairy Sci. 67:110114 .

Burvenich, C., V. Van Merris, J. Mehrzad, A. Diez-Fraile, and L. Duchateau. 2003. Severity of $E$. coli mastitis is mainly determined by cow factors. Vet. Res. 34:521-564.

CAST (Council for Agricultural Science and Technology). 2003. Mycotoxins: Risk in plant, animal and human systems. Task force report no. 139. CAST, Ames, IA.

Chestnut, A. B., P. D. Anderson, M. A. Cochran, H. A. Fribourg, and K. D. Gwinn. 1992. Effects of hydrated sodium calcium aluminosilicate on fescue toxicosis and mineral absorption. J. Anim. Sci. 70:2838-2846.

Dann, H. M., J. K. Drackley, G. C. McCoy, M. F. Hutjens, and J. E. Garrett. 2000. Effects of yeast culture (Saccharomyces cerevisiae) on prepartum intake and postpartum intake and milk production of Jersey cows. J. Dairy Sci. 83:123-127.

Demetriou, J. A., P. A. Drewes, and J. B. Gin. 1974. Ceruloplasmin. Pages 857-865 in Clinical Chemistry. C. Cannon and W. W. Winkelman, ed. Harper and Row, Hagerstown, MD.

Diaz, D. E., W. M. Hagler, J. T. Blackwelder, J. A. Eve, B. A. Hopkins, K. L. Anderson, F. T. Jones, and L. W. Whitlow. 2004. Aflatoxin binders II: Reduction of aflatoxin M1 in milk by sequestering agents of cows consuming aflatoxin in feed. Mycopathologia 157:233-241.

do Amaral, B. C., E. E. Conner, S. Tao, J. Hayen, J. Bubolz, and G. E. Dahl. 2010. Heat stress abatement during the dry period influences prolactin signaling in lymphocytes. Domest. Anim. Endocrinol. 38:38-45.

Doležal, P., J. Dvořáček, J. Doležal, J. Čermáková, L. Zeman, and K. Szwedziak. 2011. Effect of feeding yeast culture on ruminal fermentation and blood indicators of Holstein dairy cows. Acta Vet. Brno 80:139-145.

EFSA (European Food Safety Authority). 2004. Opinion of the scientific panel on contaminants in the food chain on a request from the Commission related to aflatoxin B1 as undesirable substance in animal feed. EFSA J. 39:1-27.

Elvinger, F., R. P. Natzke, and P. J. Hansen. 1992. Interactions of heat stress and bovine somatotropin affecting physiology and immunology of lactating cows. J. Dairy Sci. 75:449-462.

FDA (Food and Drug Administration). 2000. Guidance for industry: Action levels for poisonous or deleterious substances in human food and animal feed. Accessed Jan. 20, 2018. https://www.fda.gov/food/ guidanceregulation/guidancedocumentsregulatoryinformation/ ucm077969.htm\#afla.

Fink-Gremmels, J. 2008. The role of mycotoxins in the health and performance of dairy cows. Vet. J. 176:84-92.

Firmin, S., D. P. Morgavi, A. Yiannikouris, and H. Boudra. 2011. Effectiveness of modified yeast cell wall extracts to reduce aflatoxin B1 absorption in dairy ewes. J. Dairy Sci. 94:5611-5619.

Gakidis, M. A., X. Cullere, T. Olson, J. L. Wilsbacher, B. Zhang, S. L. Moores, K. Ley, W. Swat, T. Mayadas, and J. S. Brugge. 2004. Vav GEFs are required for $\beta 2$ integrin-dependent functions of neutrophils. J. Cell Biol. 166:273-282. 
Galvano, F., A. Pietri, T. Bertuzzi, G. Fusconi, M. Galvano, A. Piva, and G. Piva. 1996. Reduction of carry-over of aflatoxin from cow feed to milk by addition of activated carbons. J. Food Prot. 59:551-554.

George, J. W., J. Snipes, and V. M. Lane. 2010. Comparison of bovine hematology reference intervals from 1957 to 2006. Vet. Clin. Pathol. 39:138-148.

Gourama, H., and L. B. Bullerman. 1995. Aspergillus flavus and Aspergillus parasiticus: Aflatoxigenic fungi of concern in foods and feeds: A review. J. Food Prot. 58:1395-1404.

Guthrie, L. D. 1979. Effects of aflatoxin in corn on production and reproduction in dairy cattle. J. Dairy Sci. 62(Suppl.):134. (Abstr.)

Hasheminya, S. M., and J. Dehghannya. 2013. Strategies for decreasing aflatoxin in livestock feed and milk. Int. Res. J. Appl. Basic Sci. 4:1506-1510.

Heegaard, P. M. H., D. L. Godson, M. J. M. Toussaint, K. Tjørnehøj, L. E. Larsen, B. Viuff, and L. Rønsholt. 2000. The acute phase response of haptoglobin and serum amyloid A (SAA) in cattle undergoing experimental infection with bovine respiratory syncytial virus. Vet. Immunol. Immunopathol. 77:151-159.

Hussein, H. S., and J. M. Brasel. 2001. Toxicity, metabolism, and impact of mycotoxins on humans and animals. Toxicology 167:101134.

IARC (International Agency for Research on Cancer). 2002. Some traditional herbal medicines, some mycotoxins, naphthalene and styrene. Summary of data reported and evaluation. Pages 171-175 in IARC Monographs on the Evaluation of the Carcinogenic Risk to Humans. Vol. 82. Int. Agency Res. Cancer, Lyon, France.

Jain, S., V. Gautam, and S. Naseem. 2011. Acute-phase proteins: As diagnostic tool. J. Pharm. Bioallied Sci. 3:118-127.

Jensen, G. S., S. G. Carter, S. G. Reeves, L. E. Robinson, and K. F. Benson. 2015. Anti-inflammatory properties of a dried fermentate in vitro and in vivo. J. Med. Food 18:378-384.

Jiang, Y. H., H. J. Yang, and P. Lund. 2012. Effect of aflatoxin B1 on in vitro ruminal fermentation of rations high in alfalfa hay or ryegrass hay. Anim. Feed Sci. Technol. 175:85-89.

Jouany, J. P. 2007. Methods for preventing, decontaminating and minimizing the toxicity of mycotoxins in feeds. Anim. Feed Sci. Technol. 137:342-362

Kampen, A. H., T. Tollersrud, S. Larsen, J. A. Roth, D. E. Frank, and A. Lund. 2004. Repeatability of flow cytometric and classical measurement of phagocytosis and respiratory burst in bovine polymorphonuclear leukocytes. Vet. Immunol. Immunopathol. 97:105-114.

Kissell, L., S. Davidson, B. A. Hopkins, G. W. Smith, and L. W. Whitlow. 2013. Effect of experimental feed additives on aflatoxin in milk of dairy cows fed aflatoxin-contaminated diets. J. Anim. Physiol. Anim. Nutr. (Berl.) 97:694-700.

Kutz, R. E., J. D. Sampson, L. B. Pompeu, D. R. Ledoux, J. N. Spain, M. Vazquez-Anon, and G. E. Rottinghaus. 2009. Efficacy of Solis, NovasilPlus, and MTB-100 to reduce aflatoxin M1 levels in milk of early to mid-lactation dairy cows fed aflatoxin B1. J. Dairy Sci. 92:3959-3963.

Liu, Y., and F. Wu. 2010. Global burden of aflatoxin-induced hepatocellular carcinoma: A risk assessment. Environ. Health Perspect. 118:818-824.

Maki, C. R., A. D. Thomas, S. E. Elmore, A. A. Romoser, R. B. Harvey, H. A. Ramirez-Ramirez, and T. D. Phillips. 2016. Effects of calcium montmorillonite clay and aflatoxin exposure on dry matter intake, milk production, and milk composition. J. Dairy Sci. 99:1039-1046.

Makimura, S., and N. Suzuki. 1982. Quantitative determination of bovine serum haptoglobin and its elevation in some inflammatory diseases. Nihon Juigaku Zasshi. 44:15-21.

Martinez, N., F. S. Lima, R. S. Bisinotto, L. F. Greco, E. S. Ribeiro, F. Maunsell, K. N. Galvão, C. A. Risco, and J. E. P. Santos. 2012 Evaluation of peripartal calcium status, energetic profile, and neutrophil function in dairy cows at low or high risk of developing uterine disease. J. Dairy Sci. 95:7158-7172.

Mehrzad, J., H. Dosogne, E. Meyer, R. Heyneman, and C. Burvenich. 2001. Respiratory burst activity of blood and milk neutrophils in dairy cows during different stages of lactation. J. Dairy Res. 68:399-415.

Mojtahedi, M., M. D. Mesgaran, S. A. Vakili, and M. Hayati-Ashtiani. 2013. Effect of aflatoxin B1 on in vitro rumen microbial fermentation responses using batch culture. Annu. Rev. Res. Biol. 3:686693.

Nakajima, T., S. Watanabe, Y. Sato, T. Kameya, T. Hirota, and Y. Shimosato. 1982. An immunoperoxidase study of S-100 protein distribution in normal and neoplastic tissues. Am. J. Surg. Pathol. 6:715-727.

NRC. 2001. Nutrient Requirements of Dairy Cattle. 7th rev. ed. Natl. Acad. Press, Washington, DC.

Ogunade, I. M., K. G. Arriola, Y. Jiang, J. P. Driver, C. R. Staples, and A. T. Adesogan. 2016. Effects of 3 sequestering agents on milk aflatoxin M1 concentration and the performance and immune status of dairy cows fed diets artificially contaminated with aflatoxin B1. J. Dairy Sci. 99:6263-6273.

Pantaya, D., D. P. Morgavi, M. Silberberg, F. Chaucheyras-Durand, C. Martin, K. G. Wiryawan, and H. Boudra. 2016. Bioavailability of aflatoxin B1 and ochratoxin A, but not fumonisin B1 or deoxynivalenol, is increased in starch-induced low ruminal $\mathrm{pH}$ in nonlactating dairy cows. J. Dairy Sci. 99:9759-9767.

Patra, A. K. 2012. The use of live yeast products as microbial feed additives in ruminant nutrition. Asian J. Anim. Vet. Adv. 7:366-375.

Paul, P. S., D. W. Johnson, C. J. Mirocha, F. F. Soper, C. C. Thoen, C. C. Muscoplat, and A. F. Weber. 1977. In vitro stimulation of bovine peripheral blood lymphocytes: Suppression of phytomitogen and specific antigen lymphocyte responses by aflatoxin. Am. J. Vet. Res. 38:2033-2035.

Petersen, H. H., A. K. Ersbøll, C. S. Jensen, and J. P. Nielsen. 2002. Variation of serum haptoglobin concentration in slaughter pigs of different health status. Prev. Vet. Med. 54:325-335.

Pier, A. C. 1992. Major biological consequences of aflatoxicosis in animal production. J. Anim. Sci. 70:3964-3967.

Poppy, G. D., A. R. Rabiee, I. J. Lean, W. K. Sanchez, K. L. Dorton, and P. S. Morley. 2012. A meta-analysis of the effects of feeding yeast culture produced by anaerobic fermentation of Saccharomyces cerevisiae on milk production of lactating dairy cows. J. Dairy Sci. 95:6027-6041.

Price, R. L., J. H. Paulson, O. G. Lough, C. Gingg, and A. G. Kurtz. 1985. Aflatoxin conversion by dairy cattle consuming naturallycontaminated whole cottonseed. J. Food Prot. 48:11-15.

Queiroz, O. C. M., J. H. Han, C. R. Staples, and A. T. Adesogan. 2012. Effect of adding a mycotoxin-sequestering agent on milk aflatoxin M1 concentration and the performance and immune response of dairy cattle fed an aflatoxin B1-contaminated diet. J. Dairy Sci. 95:5901-5908.

Reddy, K. R. N., B. Salleh, B. Saad, H. K. Abbas, C. A. Abel, and W T. Shier. 2010. An overview of mycotoxin contamination in foods and its implications for human health. Toxin Rev. 29:3-26.

Rodrigues, I., and K. Naehrer. 2012. A three-year survey on the worldwide occurrence of mycotoxins in feedstuffs and feed. Toxins (Basel) 4:663-675.

Sales, A. C., and T. Yoshizawa. 2005. Mold counts and Aspergillus section Flavi populations in rice and its by-products from the Philippines. J. Food Prot. 68:120-125.

Salter, R., D. Douglas, M. Tess, B. Markovsky, and S. J. Saul. 2006 Interlaboratory study of the charm ROSA safe level aflatoxin M1 quantitative lateral flow test for bovine raw milk. J. AOAC Int. 89:1327-1334.

Schingoethe, D. J., K. N. Linke, K. F. Kalscheur, A. R. Hippen, D. R. Rennich, and I. Yoon. 2004. Feed efficiency of mid-lactation dairy cows fed yeast culture during summer. J. Dairy Sci. 87:4178-4181.

Silvestre, F. T., T. S. Carvalho, P. C. Crawford, J. E. Santos, C. R Staples, T. Jenkins, and W. W. Thatcher. 2011. Effects of differential supplementation of fatty acids during the peripartum and breeding periods of Holstein cows: II. Neutrophil fatty acids and function, and acute phase proteins. J. Dairy Sci. 94:2285-2301.

Sulzberger, S. A., S. Melnichenko, and F. C. Cardoso. 2017. Effects of clay after an aflatoxin challenge on aflatoxin clearance, milk pro- 
duction, and metabolism of Holstein cows. J. Dairy Sci. 100:18561869.

Thomas, L. 1998. Clinical Laboratory Diagnostics: Use and Assessment of Clinical Laboratory Results. 1st ed. Verlagsgesellschaft, Frankfurt/Main, Germany.

Tothova, C., O. Nagy, and G. Kovac. 2014. Acute phase proteins and their use in the diagnosis of diseases in ruminants: A review. Vet. Med. (Praha) 59:163-180.

Upadhaya, S. D., M. A. Park, and J. K. Ha. 2010. Mycotoxins and their biotransformation in the rumen: A review. Asian-australasian. J. Anim. Sci. 23:1250-1260.

Van Soest, P. J., J. B. Robertson, and B. A. Lewis. 1991. Methods for dietary fiber, neutral detergent fiber and non-starch polysaccharides in relation to animal nutrition. J. Dairy Sci. 74:3583-3597.

Velde, B., and A. Meunier. 2008. Fundamentals of clay mineral crystal structure and physicochemical properties. Pages 3-74 in The Origin of Clay Minerals in Soils and Weathered Rocks. B. Velde and A. Meunier, ed. 1st ed. Springer, Berlin, Germany
Xiao, J. X., G. M. Alugongo, R. Chung, S. Z. Dong, S. L. Li, I. Yoon, Z. H. Wu, and Z. J. Cao. 2016. Effects of Saccharomyces cerevisiae fermentation products on dairy calves: Ruminal fermentation, gastrointestinal morphology, and microbial community. J. Dairy Sci. 99:5401-5412

Xiong, J. L., Y. M. Wang, T. D. Nennich, Y. Li, and J. X. Liu. 2015. Transfer of dietary aflatoxin B1 to milk aflatoxin M1 and effect of inclusion of adsorbent in the diet of dairy cows. J. Dairy Sci. 98:2545-2554.

Zaworski, E. M., C. M. Shriver-Munsch, N. A. Fadden, W. K. Sanchez, I. Yoon, and G. Bobe. 2014. Effects of feeding various dosages of Saccharomyces cerevisiae fermentation product in transition dairy cows. J. Dairy Sci. 97:3081-3098.

Zhu, W., B. X. Zhang, K. Y. Yao, I. Yoon, Y. H. Chung, J. K. Wang, and J. X. Liu. 2016. Effects of supplemental levels of Saccharomyces cerevisiae fermentation product on lactation performance in dairy cows under heat stress. Asian-australas. J. Anim. Sci. 29:801-806. 